\title{
Correction to: Three-Dimensional Quantification of Spheroid Degradation- Dependent Invasion and Invadopodia Formation
}

\author{
Cameron Goertzen ${ }^{1}$, Denise Eymael ${ }^{1}$ and Marco Magalhaes ${ }^{1,2,3^{*}}$
}

\section{Correction to: Biological Procedures Online (2018) 20:20 https://doi.org/10.1186/s12575-018-0085-6}

It has come to the authors' attention that the representative image of the unstimulated UMSCC1 spheroid at Day 1 in Fig. 1a was selected from the wrong data set. The image in the original article [1] was taken from a data set for another study by the authors [2]. The revised Fig. 1 including a representative image of the unstimulated UMSCC1 spheroid at Day 1 taken from the correct study data set is available in this erratum.

\footnotetext{
Author details

${ }^{1}$ Cancer Invasion and Metastasis Laboratory, Faculty of Dentistry, University of Toronto, Toronto, Canada. ${ }^{2}$ Oral Pathology and Oral Medicine, Faculty of Dentistry, University of Toronto, 124 Edward Street, room 495, Toronto, ON M5G1G6, Canada. ${ }^{3}$ Sunnybrook Health Sciences Centre, Toronto, ON, Canada.
}

Published online: 21 May 2019

\section{References}

1. Goertzen C, et al. Three-Dimensional Quantification of Spheroid Degradation-Dependent Invasion and Invadopodia Formation. Biol Proced Online. 2018;20(1):20. https://doi.org/10.1186/s12575-018-0085-6.

2. Goertzen C, et al. Oral inflammation promotes oral squamous cell carcinoma invasion. Oncotarget. 2018;9(49):29047. https://doi.org/10.18632/ oncotarget.25540.

\footnotetext{
* Correspondence: marco.magalhaes@utoronto.ca

${ }^{1}$ Cancer Invasion and Metastasis Laboratory, Faculty of Dentistry, University of Toronto, Toronto, Canada

${ }^{2}$ Oral Pathology and Oral Medicine, Faculty of Dentistry, University of

Toronto, 124 Edward Street, room 495, Toronto, ON M5G1G6, Canada

Full list of author information is available at the end of the article
}

(c) The Author(s). 2019 Open Access This article is distributed under the terms of the Creative Commons Attribution 4.0 International License (http://creativecommons.org/licenses/by/4.0/), which permits unrestricted use, distribution, and reproduction in any medium, provided you give appropriate credit to the original author(s) and the source, provide a link to the Creative Commons license, and indicate if changes were made. The Creative Commons Public Domain Dedication waiver (http://creativecommons.org/publicdomain/zero/1.0/) applies to the data made available in this article, unless otherwise stated. 

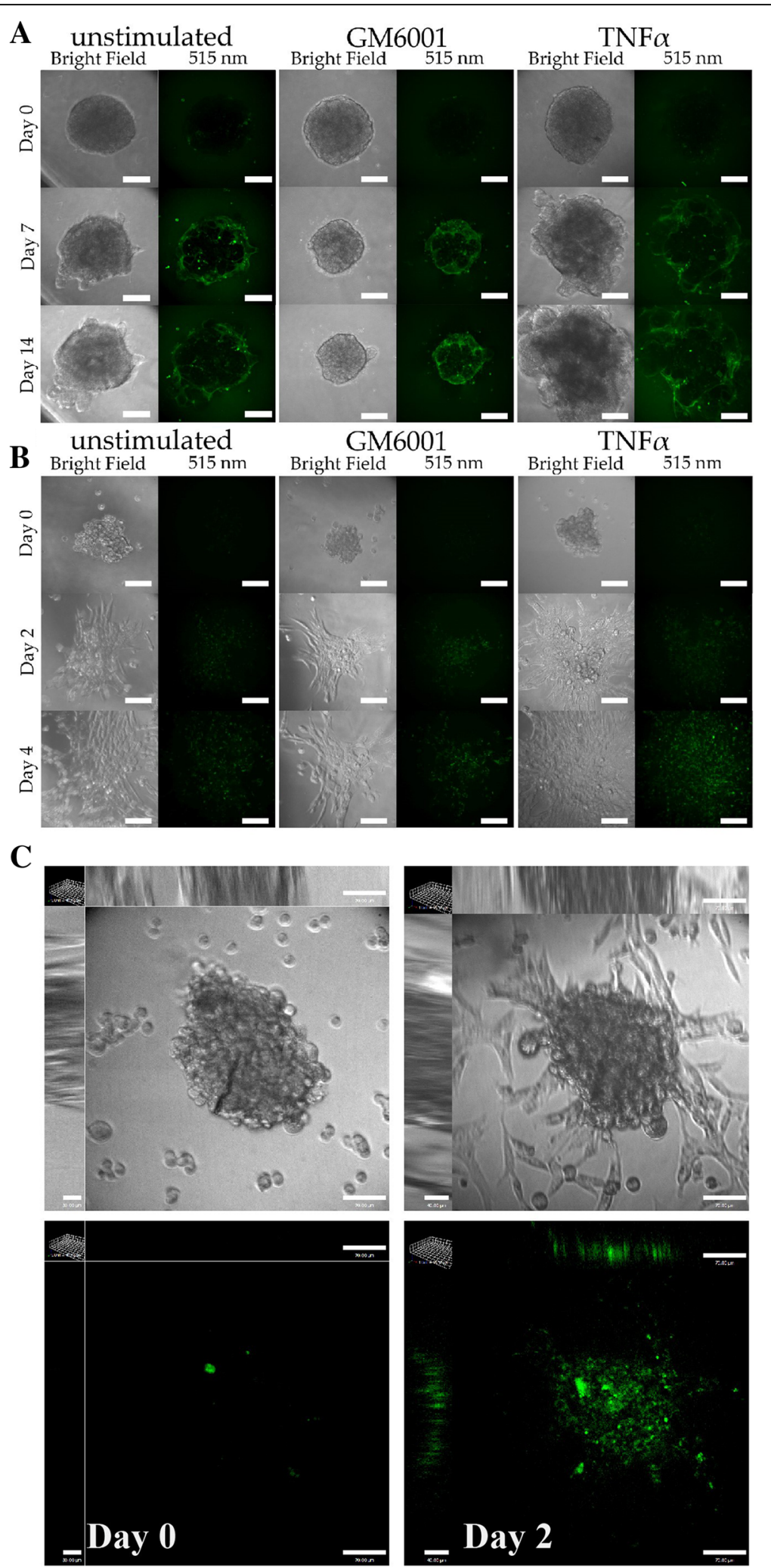

Fig. 1 Representative images of spheroid Geltrex ${ }^{\mathrm{TM}}$ degradation. Representative confocal images of UMSCC1 (a) or MDA-MB-231 (b) spheroids causing Geltrex ${ }^{\mathrm{TM}}$ degradation signalling at Day 0, 7, and 14 or Day 0, 2, and 4, respectively. Spheroid volume was revealed through bright-field imaging and Geltrex ${ }^{\mathrm{TM}}$ degradation through $488 \mathrm{~nm}$ excitation/515 emission. c 3D images of MDA-MB-231 cells showing both a spheroid and a background of highly invasive cells that attached to the bottom of the slides. Scale bar, $100 \mu \mathrm{m}$. Images are representative of three repetitions 